\title{
Effect of yeast treated bovine blood-rumen content mixture on performance and blood profile of weaner rabbits
}

${ }^{1}$ Mbahi, T. F., ${ }^{2}$ Adi, A., ${ }^{1}$ Yakubu, B. and ${ }^{2}$ Wafar, R. J.

${ }^{\prime}$ Department of Animal Science and Range Management,

Modibbo Adama University of Technology, Yola, Adamawa State.

${ }^{2}$ Department of Animal production and Health,

Federal University Wukari, Taraba State

Corresponding Author: tfmbahi@ yahoo.com; +2348036521667

Abstract

$\overline{\text { The study was conducted to evaluate the effect of yeast treated Bovine blood-rumen content }}$ mixture (YTBRM) on performance of 60 weaner rabbits with an average weight of $501.96 \pm$ $0.22 \mathrm{~g}$. The rabbits were randomly assigned to five dietary treatments with five replicates in a completely randomized design. T1, T2, T3, T4 and T5 had 0\%, 10\%, 20\%, 30\% and 40\% YTBRM. Data were collected on growth performance, carcass characteristics and haematological indices. At the end of the experiment, 4 rabbits were randomly selected from each treatment and slaughtered to determine the effect of graded levels of YTBRM on carcass yield and internal organs characteristics. The result of growth performance revealed that all parameters measured were significantly $(P<0.05)$ affected by the dietary inclusion of $Y T B R M$ except for feed conversion ratio which ranged from 3.05 in $T 1$ to 3.64 in T2. Average daily feed intake was significantly $(P<0.05)$ higher $(101.69)$ in treatment T5 while the other treatment groups were similar. Average daily weight gain were significantly higher in T5 $(29.72 \mathrm{~g})$ and $T 4(28.05 \mathrm{~g})$ while the least value was obtained in T2 (25.46g). Carcass yield was significant $(P<0.05)$ across the treatment groups. Dressing percentages were significantly $(p<0.05)$ higher in T2 $(82.35 \%), T 1(77.62 \%)$ and T4 $(74.08 \%)$ than T5 $(63.57 \%)$ and T3 (69.79\%). Result of the internal organs shows that they were all similar across the treatment groups. Haematological and biochemical indices shows no significant diffrerence $(P>0.05)$ in all the parameters evaluated. It could be concluded from this study that YTBRM can be included up to $40 \%$ in weaner rabbits diet without adverse effect on the growth performance, blood profile, carcass and internal organs characteristics.

Keywords: Performance, Bovine blood- rumen mixture, Yeast, weaner rabbit, Carcass

\section{Introduction}

Protein intake in Nigeria to both animal and human being is still a main problem since it is lacking both in quantity and quality without proper ways of addressing them while the population is on the increase (Egbunike, 1997). Animal products contribute about $15-20 \%$ of the total protein intake of an average Nigerian contrary to $33 \%$ recommended by Food and Agricultural Organization (Taiwo et al., 2004). This wide gap between the recommended protein intake and the average consumption rate has resulted to increase in demand for the production of animal protein to the Nigerian populace. There is urgent need to increase the production of animals with short generation interval such as rabbit in order to bridge this gap. Rabbit production is esteemed as a veritable means of meeting the animal protein needs of the population due to its obvious advantages over other nonruminants (Ojebiyi et al., 2010). However, the major hindrance to the production of rabbit is the cost of feeds. Feed accounts for about $70 \%$ of the total cost of production and remains a main threat to the expansion 
of this sector in Nigeria due to the stiff competition for feedstuffs by man and industry. Sourcing for alternative feeds especially energy and protein sources is therefore imperative. The use of byproducts such as wastes from abattoir and agro-industries have been reported (Dairo et al., 2005). Rumen content as well as bovine blood is an abattoir by-products which if not properly handled can cause nuisance in the environment. The rumen being the vat where fermentation of feed takes place contains various microorganisms such as the phycomycetous fungi, protozoa, bacteria and others that are involved in this process (Preston, 1991). According to Adeniji and Balogun (2002) and Dairo (2005) the composition and potential of rumen content and blood mixture qualifies them as good sources of protein for monogastric animals. Study on the use of bovine rumen - blood meal by many people in its mash form in rabbit production resulted in significant drop in feed intake and weight gain (Togun et al., 2009; Dairo et al.,2005). Yeast which is used to aid fermentation was added to enhance the digestibility of the rumen content because it has the potential of softening the fibre content (Mohammed et al. 2008). However, there is paucity of information on the optimum level of inclusion of yeast treated bovine rumen content in rabbit nutrition. The study therefore was conducted to evaluate the optimum level of inclusion of yeast treated bovine blood-rumen content mixture on the growth performance, carcass characteristics, internal organ weight and blood profile of weaner rabbits.

\section{Materials and methods Study site}

The study was conducted at the Small Unit of the Teaching and Research Farm of the
Department of Animal Science, Taraba State University, Jalingo, Jalingo lies between latitude $8^{0} 53^{1 "}$ "North and longitude $11^{0} 23^{1 \text { " }}$ East of the equator in the guinea savannah zone of northern Nigeria. There are two main seasons existing in the area, the dry and rainy seasons. It has an annual rainfall between $1000-15000 \mathrm{~mm}$ with a temperature range of $30-42^{\circ} \mathrm{c}$ depending on the season (Taraba State Diary, 2008).

\section{Collection and processing of blood and rumen content}

Fresh bovine rumen content and blood were collected from the central Abattoir in Jalingo and spread to sun dry on a concrete floor for five days. It was latter ground to $2 \mathrm{~mm}$ particle size, mixed with live yeast and then stored.

Experimental diets, design and management

Five experimental diets were formulated using bovine rumen content and blood content (BRBM) at $0,10,20,30$ and $40 \%$ and were designated as T1, T2, T3, T4 and T5, respectively. Sixty weaner rabbits sourced within Jalingo metropolis were randomly allotted into the five treatment groups with 12 rabbits in each treatment and replicated four times with three rabbits per replicate in a completely randomized design. Each hutch was thoroughly cleaned and disinfected two weeks before the arrival of the rabbits. The rabbits were dewormed using Piperazine $®$, antibiotics and coccidiostats were also administered against bacterial and coccidial infections.

\section{Data collection Growth performance}

Feed intake was determined by subtracting the left-over of the feed supplied the previous day from the quantity given. Each rabbit was weighed at the beginning of the experiment and thereafter weekly using weighing scale. Weight gain was then 
Mbahi, Adi, Yakubu and Wafar

Table 1: Percentage composition of experimental diets

\begin{tabular}{|c|c|c|c|c|c|}
\hline \multirow[b]{2}{*}{ Ingredients } & \multicolumn{4}{|c|}{ Inclusion levels of BRBM } & \multirow[b]{2}{*}{ T5 } \\
\hline & $\mathrm{T} 1$ & $\mathrm{~T} 2$ & $\mathrm{~T} 3$ & T4 & \\
\hline Maize & 57.16 & 57.16 & 57.16 & 57.16 & 57.36 \\
\hline Maize bran & 17.00 & 17.00 & 17.00 & 17.00 & 17.00 \\
\hline Groundnut cake & 19.69 & 17.72 & 15.75 & 13.78 & 11.87 \\
\hline Fish meal & 3.00 & 3.00 & 3.00 & 3.00 & 3.00 \\
\hline BRBM & 0.00 & 1.97 & 3.94 & 5.91 & 7.88 \\
\hline Yeast & 0.50 & 0.50 & 0.50 & 0.50 & 0.50 \\
\hline Bone meal & 2.00 & 2.00 & 2.00 & 2.00 & 2.00 \\
\hline Premix* & 0.15 & 0.15 & 0.15 & 0.15 & 0.15 \\
\hline Salt & 0.50 & 0.50 & 0.50 & 0.50 & 0.50 \\
\hline Total & 100 & 100 & 100 & 100 & 100 \\
\hline \multicolumn{6}{|c|}{ Calculated Analysis } \\
\hline Crude protein & 17.43 & 17.74 & 18.06 & 18.38 & 18.69 \\
\hline Crude fibre & 3.33 & 3.33 & 3.33 & 3.33 & 3.33 \\
\hline Ether extracts & 3.48 & 3.37 & 3.27 & 3.27 & 3.17 \\
\hline $\mathrm{ME}(\mathrm{Kcal} / \mathrm{Kg})$ & 3630.84 & 3616.72 & 3612.81 & 3607.23 & 3602.86 \\
\hline \multicolumn{6}{|c|}{$\begin{array}{l}\text { *Vitamin-Mineral premix (Bio -mix) provided per kg include the following: Vitamin A 500 IU; Vitamin D3, 888,000 iu; Vitamin E, } \\
\text { 12,200mg; Vitamin K3 15,000mg; Vitamin B1, 100mg; B2, 200mg; B6, 1500mg; Näcin, 1200mg; Pathothenic acid, 2000mg; Biotic, 100mg; } \\
\text { Vitamin B12, 3000mg; Folic acid, 1500mg; Chlorine chloride, 60,000mg; Manganese, 10,000mg; Iron, 1500mg; Zinc, 800mg; Copper, } \\
\text { 400mg; Iodine, 80mg; Cobalt, 40mg; Selenium, 8000mg. }\end{array}$} \\
\hline \multicolumn{2}{|c|}{$\begin{array}{l}\text { TI = Bovine blood-rumen mixture sole } \\
\text { T3= Bovine blood-rumen mixture }+20 \% \text { yeast } \\
\text { T5=Bovine blood-rumen mixture }+40 \% \text { yeast }\end{array}$} & \multicolumn{4}{|c|}{$\begin{array}{l}\text { T2= Bovine blood-rumen mixture }+10 \% \text { yeast } \\
\text { T4 =Bovine blood-rumen mixture }+30 \% \text { yeast }\end{array}$} \\
\hline
\end{tabular}

determined by subtracting weight obtained in two consecutive weeks. Feed intake and weight recorded were used to calculate feed conversion ratio (FCR).

\section{Carcass evaluation}

Twenty (20) rabbits made up of four (4) rabbits from each treatment group were randomly selected and slaughtered for carcass evaluation. Animals were slaughtered, bled, dressed by flaying, eviscerated, split and weighed. Internal organs weight was determined using an electronic $\left(\right.$ master $^{\mathrm{R}}$ ) digital scale and expressed as percentage live-weight. Dressing percentage was determined by dividing the dressed weight by the slaughter weight and multiplied the result by one hundred.

\section{Haematological and biochemical indices}

Blood samples were collected from four rabbits per treatment for determination of haematology and serum biochemical parameters on the last day of the experiment
( $8^{\text {th }}$ week). $5 \mathrm{mLs}$ of blood samples were collected from ear vein using a disposable needle and syringe into specimen test tubes containing Ethylene Diamine Tetra Acetic Acid (EDTA) as anticoagulant for haematological parameters (Packed Cell Volume, Red Blood Cells, Heamoglobin Concentration and White Blood Cells). The Erythrocytic Component; Mean Corpuscular Volume (MCV), Mean Corpuscular Heamoglobin (MCH) and Mean Corpuscular Heamoglobin Concentration (MCHC) were determined using the formula described by Jain (1993), while another $5 \mathrm{ml}$ were placed in test tubes without anticoagulant to determine the serological parameters (total protein, albumin, urea, cholesterol, globulin and glucose).

\section{Chemical analysis}

Proximate composition of experimental diets, yeast treated bovine rumen-blood mixture were analysed using the methods 
described by A.O.A.C. (2000).

\section{Statistical analysis}

The data obtained during the experiment were analysed according to the ANOVA model, using the ONEWAY procedure of SPSS (2016) and where significant differences exist, Duncan's multiple range test option of the same statistical software was employed.

\section{Results and discussion}

Proximate composition of Yeast Treated Bovine Rumen-Blood Mixture (YTBRM)

The results of the proximate composition of the yeast treated bovine blood-rumen content mixture is presented in Table 2 . The result showed that YTBBRM had $92.50 \%$ dry matter (DM), 59.00\% Crude protein $(\mathrm{CP}), 14.00 \%$ crude fibre (CF), $18.50 \%$ Ash, $14.00 \%$ Ether Extract (EE) and $25.50 \%$ Nitrogen extract (NFE), respectively. The $\mathrm{CP}$ content is higher than 46.1\% reported by Odunsi (2003), 33.81\% reported by Dairo et al. (2005) and $13.56 \%$ by Okpanachi et al. (2010) for untreated bovine rumen blood mixture. The values of ash, crude fibre and metabolizable energy $(\mathrm{kcal} / \mathrm{kg})$ are higher than $7.49 \%, 24.58 \%$ and $2278.58 \mathrm{kcal} / \mathrm{kg}$ energy reported by Adeniji and Balogun et al. (2000). Variations in chemical composition could be attributed to the addition of yeast to the bovine rumen blood mixture which shows improvement in the nutrient composition. Dairo et al. (2005) also attributed the change in composition of bovine rumen blood mixture could be due to the type of pasture consumed by the slaughtered animal, specie differences and the proportion of the constituent mixtures.

Table2: Proximate composition of Bovine Rumen-Blood Mixture (\%/DM)

\begin{tabular}{|c|c|}
\hline Nutrients & \% Composition \\
\hline Dry matter & 92.50 \\
\hline Crude protein & 59.00 \\
\hline Crude fibre & 14.00 \\
\hline Ether extracts & 1.07 \\
\hline Ash & 17.50 \\
\hline Nitrogen free extracts & 8.43 \\
\hline${ }^{+} \mathrm{ME}(\mathrm{Kcal} / \mathrm{Kg})$ & 2568.94 \\
\hline
\end{tabular}

Performance characteristics of weaned rabbits fed Yeast Treated Bovine RumenBlood Mixture

The growth performance of weaned rabbits fed graded levels of yeast treated bovine rumen- blood mixture (YTBRM) is presented in Table 3. The result showed significant differences $(\mathrm{P}<0.05)$ in all the parameters measured except feed conversion ratio. Final weight and total feed intake increased $(P<0.05)$ progressively with increasing levels of YTBRM in the diets. The result is similar to report by Mohammed et al. (2005) that increase in protein content of the feed increases intake. The increase in feed intake obtained could be attributed to increase in appetite resulting from the addition of yeast which could have changed unpleasant smell of the diets. Odunsi (2003) reported that the inclusion of untreated blood meal and rumen content impart obnoxious odour to the diet thereby causing decrease in feed intake. The improved weight gain of rabbits fed YTBRM diets could also be attributed to the balance of nutrients content of the diets which were efficiently metabolized for growth 
Mbahi, Adi, Yakubu and Wafar

Table 3: Performance of Weaned Rabbits Fed Yeast Bovine Rumen-Blood Mixture

\begin{tabular}{|c|c|c|c|c|c|c|}
\hline \multirow[b]{2}{*}{ Parameter } & \multicolumn{4}{|c|}{ Dietary Treatment(s) } & \multirow[b]{2}{*}{ T5 } & \multirow[b]{2}{*}{ SEM } \\
\hline & T1 & $\mathrm{T} 2$ & T3 & $\mathrm{T} 4$ & & \\
\hline Initial weight (g) & 504.00 & 500.00 & 501.67 & 500.00 & 504.17 & $4.99^{\mathrm{ns}}$ \\
\hline Final weight $(\mathrm{g})$ & $2039.58^{\mathrm{a}}$ & $1925.84^{\mathrm{b}}$ & $1995.83^{b}$ & $2070.84^{\mathrm{a}}$ & $2168.75^{\mathrm{a}}$ & $19.10^{*}$ \\
\hline Total Weight Gain (g) & $1535.41^{\mathrm{ab}}$ & $1425.84^{\mathrm{c}}$ & $1494.16^{c}$ & $1570.84^{\mathrm{a}}$ & $1664.58^{\mathrm{a}}$ & $14.89^{*}$ \\
\hline Average daily weight gain $(\mathrm{g})$ & $27.41^{\mathrm{ab}}$ & $25.46^{\mathrm{c}}$ & $26.68^{c}$ & $28.05^{\mathrm{a}}$ & $29.72^{\mathrm{a}}$ & $1.17^{*}$ \\
\hline Total feed intake $(\mathrm{g})$ & $4682.50^{\mathrm{b}}$ & $5203.75^{a}$ & $5365.03^{\mathrm{a}}$ & $5467.32^{\mathrm{a}}$ & $5695.00^{\mathrm{a}}$ & $49.56^{*}$ \\
\hline Average feed intake $(\mathrm{g})$ & $83.61^{\mathrm{b}}$ & $92.92^{\mathrm{b}}$ & $95.84^{\mathrm{b}}$ & $97.63^{\mathrm{b}}$ & $101.69^{\mathrm{a}}$ & $0.94^{*}$ \\
\hline Feed conversion ratio & 3.05 & 3.64 & 3.59 & 3.48 & 3.42 & $0.17^{\mathrm{ns}}$ \\
\hline
\end{tabular}

Carcass characteristics of weaned rabbits fed Yeast Bovine Rumen-Blood mixture

The carcass characteristics and internal weight organs of rabbit fed YTBRM are presented in Table 5. The inclusion shows significant $(\mathrm{P}<0.05)$ influence across the treatment groups except for lungs, liver and kidney weights. The dressing percent obtained in this study is similar to the range values of 63.89 to $74.89 \%$ reported by Olorunsanya et al. (2007), but higher than the average of $56.50 \%$ of different European breeds reported by Lebas et al. (1997) and the difference could be due to the yeast inclusion. Kidney and liver weights were lower than the range values of 5.90 to 8.60 and 2.26 to 2.90 reported by reported by Okpanachi et al. (2010) and Ojebiyi and Saliu (2014), when the rabbits were fed untreated bovine rumen blood mixture. Internal organs weights like liver and kidney were used to study the toxicity in feeding trials, since this organs did not show significant $(\mathrm{P}>0.05)$ differences among dietary treatments. It is evident therefore, that inclusion of YTBRM in the diet did not illicit any toxic responses by the rabbits as liver and kidney which are the major organs of detoxification did not undergo any hypertrophy (Carew et al., 2003).

Table 5: Carcass analysis and internal organ weight

\begin{tabular}{|c|c|c|c|c|c|c|}
\hline \multirow[b]{2}{*}{ Parameters } & \multicolumn{3}{|c|}{ Dietary Treatment(s) } & \multirow[b]{2}{*}{$\mathrm{T} 4$} & \multirow[b]{2}{*}{ T5 } & \multirow[b]{2}{*}{ SEM } \\
\hline & T1 & $\mathrm{T} 2$ & T3 & & & \\
\hline Live weight & $2039.58^{a}$ & $1925.84^{b}$ & $1995.83^{\mathrm{b}}$ & $2070.84^{\mathrm{a}}$ & $2168.75^{\mathrm{a}}$ & $19.10^{*}$ \\
\hline Dressed weight & $1583.25^{\mathrm{a}}$ & $1586.00^{\mathrm{a}}$ & $1392.90^{\mathrm{b}}$ & $1534.25^{\mathrm{a}}$ & $1378.75^{\mathrm{b}}$ & $10.19^{*}$ \\
\hline Dressing percentage & $77.62^{\mathrm{a}}$ & $82.35^{\mathrm{a}}$ & $69.79^{\mathrm{b}}$ & $74.08^{\mathrm{a}}$ & $63.57^{\mathrm{b}}$ & $0.73^{*}$ \\
\hline \multicolumn{7}{|l|}{$\begin{array}{l}\text { Internal Organs } \\
\text { (\% live weight })\end{array}$} \\
\hline Liver & 1.09 & 1.60 & 1.39 & 1.66 & 1.79 & $0.01^{\mathrm{ns}}$ \\
\hline Kidney & 2.01 & 2.50 & 2.45 & 2.48 & 2.50 & $0.02^{\mathrm{ns}}$ \\
\hline Lungs & 1.14 & 1.45 & 1.32 & 1.42 & 1.53 & $0.01^{\mathrm{ns}}$ \\
\hline \multicolumn{7}{|c|}{$\begin{array}{l}\text { Means on the same row with different subscripts are significantly different }(p>0.05) * S E M=\text { Standar } d \text { error mean, Ns }=\text { not significant } \\
p>0.05) \text {. }\end{array}$} \\
\hline $\begin{array}{l}\text { TI= Bovine blood-rume } \\
\text { T3= Bovine blood-rume } \\
\text { T5=Bovine blood-rumer }\end{array}$ & $\begin{array}{l}\text { sole } \\
+20 \% \text { yeast } \\
+40 \% \text { yeast }\end{array}$ & $\begin{array}{l}\text { T2 =Bovi } \\
\text { T4= Bovi }\end{array}$ & $\begin{array}{l}\text { blood-rumen } \\
\text { blood-rumen }\end{array}$ & $\begin{array}{l}\text { ure }+10 \% \text { yeas } \\
\text { ure }+30 \% \text { yeas }\end{array}$ & & \\
\hline
\end{tabular}

Haematological and biochemical Indices of Weaner Rabbits Fed Yeast Treated Bovine Rumen-Blood Mixture

The result of haematological and biochemical indices of weaner rabbits fed yeast treated bovine rumen-blood mixture is shown in Table 6 . The result showed no significant difference $(\mathrm{P}<0.05)$ across the treatment groups for all the parameters measured. The PCV and $\mathrm{Hb}$ are within the normal range values of 31 to $50 \%$ and 8 to $17 \mathrm{~g} / 100 \mathrm{ml}$ respectively as reported by 
Anon (1980) for healthy young rabbits. The values obtained for all the rabbits fed various dietary levels of YTBRM indicated that there was nutritional adequacy. The $\mathrm{RBC}, \mathrm{WBC}, \mathrm{MCV}, \mathrm{MCH}$ and $\mathrm{MCHC}$ values obtained in this study fall within the normal range of 5 to $8.0,3.0$ to $12.5,60$ to 73,16 to 23 and 26 to $34 \%$, respectively reported by Anon (1980). The values of total protein, albumin and globulin contents of the serum were not influenced by inclusion levels of YTBRM. They are within the ranges of 5.81 to $6.75 \mathrm{~g} / \mathrm{dl}, 3.07$ to $4.50 \mathrm{~g} / \mathrm{dl}$ and 1.94 to $2.26 \mathrm{~g} / \mathrm{dl}$, respectively reported by Onifade and Tewe (1993) and in consonance with reference values reported by Anon (1980). This is because the total protein, globulin and albumin are averagely responsive to total protein intake and the normal values obtained indicates nutritional adequacy of the dietary protein. Schalm (1975) reported that the concentration of serum protein at any given time is a function of the nutritional status, water balance and other factors affecting the state of health of the animals. Therefore, the levels of YTBRM in the diet did not adversely affect biochemical parameters. The cholesterol levels are within the reference range of 20 to $83 \mathrm{mg} / \mathrm{dl}$. There was no change in cholesterol values as the dietary levels of YTBRM increased. Since cholesterol levels are within the normal range there will be no problems of severe liver dysfunction, nephrosis, debility or malabsorption of fat (Igwebuike et al., 2008).

Table 6: Haematological and biochemical indices of weaner rabbits fed Yeast Treated Bovine RumenBlood Mixture

Means on the same row with different subscripts are significantly different $(p>0.05) * S E M=$ Standard error mean, Ns $=$ not significant

\begin{tabular}{|c|c|c|c|c|c|c|}
\hline \multirow[b]{2}{*}{ Parameter } & \multicolumn{3}{|c|}{ Dietary treatments } & \multirow[b]{2}{*}{ T4 } & \multirow[b]{2}{*}{$\mathrm{T} 5$} & \multirow[b]{2}{*}{ SEM } \\
\hline & $\mathrm{T} 1$ & $\mathrm{~T} 2$ & $\mathrm{~T} 3$ & & & \\
\hline \multicolumn{7}{|l|}{ Hematology } \\
\hline $\operatorname{PVC}(\%)$ & 36.98 & 34.71 & 37.56 & 38.47 & 38.85 & $1.75^{\mathrm{ns}}$ \\
\hline $\mathrm{Hb}(\mathrm{g} / \mathrm{dl})$ & 10.70 & 10.90 & 10.93 & 11.20 & 11.33 & $0.46^{\mathrm{ns}}$ \\
\hline $\operatorname{MCV}(\mu 1)$ & 55.34 & 54.45 & 56.89 & 50.23 & 55.04 & $0.54 \mathrm{~ns}$ \\
\hline $\mathrm{MCH}(\mathrm{pq})$ & 17.89 & 17.84 & 17.56 & 17.45 & 17.78 & $0.17^{\mathrm{ns}}$ \\
\hline $\operatorname{MCHC}(\%)$ & 27.11 & 27.78 & 28.00 & 27.21 & 27.89 & $0.27^{\mathrm{ns}}$ \\
\hline $\mathrm{WBC}\left(\times 10^{3} \mu \mathrm{l}\right)$ & 11.44 & 12.40 & 10.26 & 13.61 & 12.68 & $1.25^{\mathrm{ns}}$ \\
\hline $\mathrm{RBC}\left(\times 10^{6} \mu \mathrm{l}\right)$ & 73.37 & 68.33 & 67.33 & 71.33 & 65.45 & $0.28^{\mathrm{ns}}$ \\
\hline \multicolumn{7}{|l|}{ Biochemical indices } \\
\hline Total protein (g/dl) & 50.00 & 50.41 & 42.70 & 47.34 & 50.09 & $3.60^{\mathrm{ns}}$ \\
\hline Albumin $(\mathrm{g} / \mathrm{dl})$ & 34.05 & 30.52 & 30.75 & 31.76 & 35.99 & $1.11^{\mathrm{ns}}$ \\
\hline Globulin (g/dl) & 25.65 & 26.67 & 29.01 & 24.69 & 27.68 & $1.21^{\mathrm{ns}}$ \\
\hline Glucose (Umo/1 & 1.94 & 2.49 & 1.63 & 1.65 & 2.09 & $0.39^{\text {ns }}$ \\
\hline Cholesterol (mg/dl) & 50.46 & 50.43 & 50.63 & 50.22 & 50.25 & $0.81^{\mathrm{ns}}$ \\
\hline
\end{tabular}

\section{Conclusion}

It could be concluded from the results obtained that YTBRM incorporated into weaner rabbits diets up to $40 \%$ did not show any adverse effect on the growth performance, blood profile, carcass and internal organs characteristics. This means the cost of producing rabbits will reduce since only yeast will be purchased and required in small quantity, while rumen content is relatively free and reduced inclusion of other expensive protein sources.

\section{References}

Adeniji, A. A. and Balogun, O. O. 2009. Utilization of Flavour Treated Blood-Rumen Content Mixture 
in the Diets of Laying Hens, Nig. J. Anim. Prod. 29(1): 34-39.

Adegbola, T. A. and Akinwande, V. O. 1981. Energy requirements of rabbits in the humid tropics. . Anim. Prod. Res. 11(2): 147-155.

A. O.A. C. 2000. Association of Analytical Chemist. Official Method of Analysis. $131 \mathrm{th}$ Edition Washington D.C, USA. Pp1018

Adeniji, A. A. and Balogun, O. O. 2002. Utilization of flavor treated blood rumencontent mixtures in the diets of laying hens. Nig. J. Anim. Prod. 29(1), 34-39.

Carew, L. B., Hardy, D., Gernat, A. G. and Zakrzewska, E. I. 2003. Heating raw velvet beans (Mucuna pruriens) reverses some antinutritional effects on organ growth, blood chemistry and organ histology in growing chickens. J. Trop. and Subtrop. Agroecosystems 1 (2-3): 267 275.

Dairo, F. A. S., Aina, O. O. and Asafa, A. R. 2005. Performance evaluation of growing rabbits fed varying levels of rumen content and blood rumen content mixture. Nig. J. Anim. Prod. 32 (1), 67-72.

Egbunike, G. N. 1997. What is Animal Science and how can Nigeria Get out of MalnourishmentIn: Ologhobo A D, Iyayi E A, Adesehinwa $\mathrm{A} \mathrm{O} \mathrm{K}$ and $\mathrm{A} \mathrm{M}$ Bamgbose Eds).stock Products. Proc. 2nd Ann. Confr. Anim. Sci. Assoc. of Nig. 1997: 16-17.

Igwebuike J. U., Anugwa, F. O. I., Raji, A. O. 1., Ehiobu, N. G. and Ikurior, S. A. 2008. Nutrient digestibility, haematological and serum biochemical indices of rabbits fed graded levels of acacia albida pods ARPN. $J$. Agric.biol. sc.vol. 3, 4, 33-41

Jain, N. C. 1993. Essentials of Veterinary Heamatology. Lea Fabiger, Philadelphia. L e b a s, F., Coudert, P., De-Rochambeau, H. and Bault, R.G. 1997. Rabbit. Husbandry, he a l th a n d production. FAO Anim. Prodion and health series no 21, Rome Italy, 203P.

Mohammed, G., Igwebuike, J. U. and Kwari, I. D. 2005. Performance of growing rabbits fed graded levels of goat rumen content. Glob. J. Pure and Applied Sc. 11(1): 39-43

Odunsi, A. A. 2003. Blend of bovine blood and rumen digesta as replacement for fishmeal and groundnut cake in layer diets. Int. J. Poultry Sc. 2(1):58-61.

Okpanachi, U., Aribido, S. O. and Daikwo, I. S. 2010. Growth and haematological response of growing rabbits to diets containing graded levels of sun-dried bovine rumen content. Africa J. Food, Agric. Nutrit. and Dev. 10(11):4444 $-4457$

Onu, P. N., Ofunma, M. O., Odukwe, C. A. and Aniecho, A. O. 2011. Effect of Different Level of Bovine Blood-rumen Content Mixture on Productive performance, carcass characteristics economics of finisher Broilers. Int. J. Food, Agric. and Vet. Sc. ISSSN 2277-20IX.

Onifade, A. A. and Tewe, O. O. 1993. Alternative tropical energy feed resources in rabbit diets: $\mathrm{Gr}$ o w t h performance, diet digestibility and blood composition. World rabbit Sc. 1: 17-24. 
Ojebiyi, O. O. and Saliu, A. S. 2014. Effects of feeding Bovine Rumen content-Blood meal $\quad(50: 50)$ mixture on performance and slaughter characteristics of growing Rabbits. J. Anim. plant sc. 24(2) 2014 pp 430-434.

Ojebiyi, O. O., Oladunjoye, I. O. and Eso, J. R. 2010. The grain replacement value of sun dried cassava (Marihot Esculenta Crantz) leat + sun dried peel meal with or without DI methionine supplementation on performance of rabbit bucks in the derived savannah zone of Nigeria, Agri.l Trop. Subtrop. 43(4): 291-299.

Olorunsanya, B., Ayoola, M. A., Fayeye, T. R., Olagunju, T. A. and Olorunsanya, E. O. 2007. Effectof replacing maize with sundried cassava wastemeal on growth performance and carcass characteristics of meat type rabbit. Livetosk Research Rural Dev. (19)4.
Pauzenga, U. 1985. Feeding parent stock. Zoo Technical International. pp 2224

Schalm, O. W., Jain, N. C. and Caroll, E. J. 1975. Veterinary Haematology. 3rdEd.Lea and $F$ e b i g e $r$, Philedelphia, U.S.A. p. 807.

Taraba State Diary 2008. State Annual Official Diary Reports.

Togun, V. A., Farinu, G. O., Ojebiyi, O. O. and Awotunde, A. I. 2009. Effect of replacing maize with a mixture of rumen content and blood meal on the performance characteristics of growing rabbits: Initial study with mash feed. World RabbitSc. 17: 21-26.

Received: $10^{\text {th }}$ October, 2017

Accepted: $1^{\text {st }}$ March, 2018 